\title{
THE EFFECT OF ROAD CROSSING ON RIVER MORPHOLOGY AND RIVERINE AQUATIC LIFE: A CASE STUDY IN KUNUR RIVER BASIN, WEST BENGAL SUVENDU, $R$. \\ http://dx.doi.org/10.4314/ejesm.v6i6.14S
}

\begin{abstract}
Received 10th September 2013; accepted 2nd December 2013

Road crossings play important role in land transport system, but improper designed stream crossing may alter the form and function of stream geomorphology, floodplain ecosystem, habitat and movement of aquatic organisms. The objective of this paper is to explain the local level impact of a road crossing on channel morphology and aquatic lives of the Kunur River, based on geomorphic survey and stream classification. This study shows a comparison between upstream and downstream reaches of Kunur River where the State Highway-14 crossed the river over a bridge. There are changing fluvio-geomorphic indicators like mean and maximum bankfull channel depth, cross-section area, flow velocity, entrenchment ratio, channel bed gradient, water level and depth, braided index (BI), pool-riffle sequence, area and shape of bars, and others taken into consideration. Results are temporally increases of $B I$ and expansions of bars. In the downstream, river channel is deeply incised by massive bed degradation and highly entrenched with high flow velocity and steep channel bed gradient, low entrenchment ratio (<2.2), low width-depth ratio (11.26) and increasing inter pool-riffle distance. Present study reveals that bank failure is a common phenomenon here with deep scours and making unsuitable environment for fish habitat. Alternatively, it has appeared to be greater deposition of fine sediment in the upstream reaches with high braiding index, area of bars. High entrenchment ratio (>2.2) and width-depth ratio (>35) also indicates well developed floodplain ecosystem here.
\end{abstract}

Key Words: Anthropogenic feature; channel morphology; bed degradation; bank failure; fine sediment

\section{Introduction}

Road-stream crossings are necessary for land transport system to cross waterways. But improperly designed crossing structure may cause for alternation of stream geomorphology and stream habitat (Resh, 2005; Wheeler et al., 2005; Merril and Gregory, 2007; Bousk et al., 2010). Mainly fish communities are vulnerable to highway crossing as their movement barrier (Jackson, 2003). These crossings also can have negative effect on the hydrology and ecology at regional level (Gregory and Brookes, 1983; Wellman et al., 2000; Hancock, 2002; Blanton and Marcus, 2009). Culverts and bridges can increase stream flow velocity, shear stress, turbulence of flow, degradation and aggradation, development of deep scours, channel braiding and downstream bank erosion (Sing, 1983; Grade and Kothyari, 1998; Richardson and Richardson, 1999; Kothyari and Ranga-Raju, 2000). Bhattacharya (1958) had

University of Kalyani, Kalyani, Nadia-741235

West Bengal, India

suvenduroy7@gmail.com criticized about the negative impact of bridge construction over the Rupnarayan River in West Bengal for the Kolkata-Mumbai national highway with unwanted number of piers. According to him, this bridge was constructed with wrong design, which is the result of heavy sedimentation on river bed, frequent flooding, and reduction of river navigability with losses of water carrying capacity. Jones et al. (2000), Wemple et al. (2001), Blanton and Marcus (2009) previously worked on the impact of roads on fluvial geomorphology with changing floodplain's form and function with intensive field measurement and application of remote sensing and GIS techniques. Waters (1995), Wheeler et al. (2005), Bouska et al. (2010), Orth and White (1999), Merril and Gregory (2007) highlighted the impact of road crossing on in-stream aquatic lives with modification of their habitat, biodiversity, movement, ecosystem, source of food and other 
functions. Booska et al. (2010) pointed out how river crossing acting as partial or check dam within channel and increased riffle spacing, which affect the fish passage. They also stated about the backwater effect and changing local level instream geomorphology using Rosgen's (1994) stream classification model. As per Rosgen (1994) Entrenchment Ratio (ER) plays an important role in delineation of interrelationship of the river to its valley and/or landform feature. It defines as the vertical containment of channel in its valley. ER is computed as the width of the flood prone area at an elevation twice the maximum bankfull depth divided by the top width of the bankfull channel. Low entrenchment $(<1.40)$ value indicates that the channel is vertically incised, whereas a high entrenchment ratio $(>2.20)$ indicates that the channel can greatly enlarge its width during high flow events and have a good floodplain.

Development of channel scours and related bed degradation are vital impacts for channel bed after construct of stream crossing with number of concrete piers. Bridge piers are modify channel morphology by increasing water velocity with turbulent flows (McKenny et al., 1995; Robert, 2003; Wang et al., 2010), and also acts as obstruction for boulders and woody debris which are directly influence channel anabranching, planform geometry, floodplain topography (Abbe and Montgomery, 2003). Scour can have a long term impact on bed degradation and affect entire channel reaches (Simon and Johnson, 1999). All of these artificial impact on stream morphology and function can have a greater negative influence on fish and other mobile aquatic species by longitudinal disconnect of the upstream and

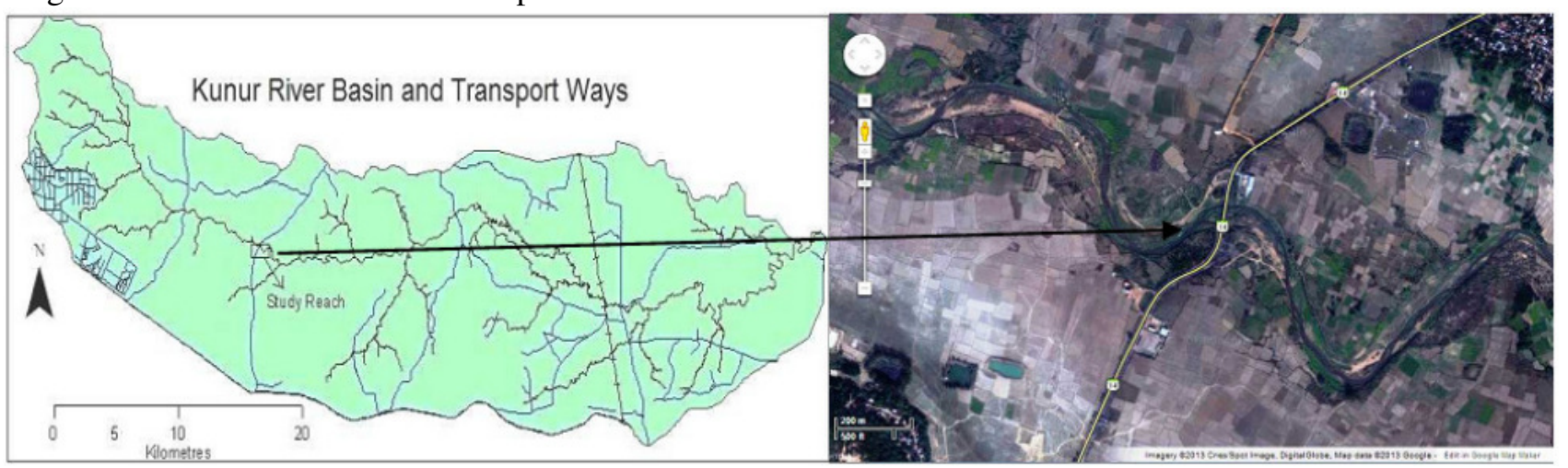

Figure 1 Location Map of the Study Reach downstream channel (Vannote et al., 1980; Merril and Gregory, 2007; Bouska et al., 2010). Vermont's Wildlife Action Plan (Vermont Department of Fish and Wildlife, 2005) identified a large number of aquatic species threatened by such road-crossing and discussed the role of crossing as barriers to movement and migration of aquatic communities and alternation of natural ecosystem. This research work is focused on the effect of single road crossing across the Kunur River with some geomorphic parameters to determine the local level changes in channel morphology and probable impact on local aquatic organisms.

\section{Methods and Materials Study Area}

One road crossing bridge across the Kunur River (major right bank tributary of the Ajay River) was selected for this reach specific study. This bridge was constructed for State Highway (S.H.) 14 to connect Panagrah and Illambazar market centers. Length of the bridge is 87 metres with 8 metres height from river bed. This bridge is standing with 10 piers, which are horizontally interconnected on the river bed with thick concrete layer (Fig. 1). In this area, Kunur is Perennial River in nature with mean discharge of 15 cumec. Hydro-geologically, this area is under unconsolidated formation with Quaternary Sediment of Sijua formation, and basement is covered by hard lateritic layer (Niyogi, 1985; GSI, 2001). Local elevation is ranging between 50-53 metres from mean sea level with mean slope variation of $2 \%$ in west to east direction. 


\section{Methods}

In this investigation, reach specific fluviogeomorphological approach with spatial variation techniques has been applied. Channel dimensions were measured at four sites. Among them, two in the upstream and two in the downstream reach. Channel cross-sections were done after identify the indicators of bankfull-stage at 10 metres and 50 metres distance from the bridge site. Longitudinal profile of about 2 kilometres including upstream and downstream, measurement of stream material size, length and area of channel bars were also done here. Several fluvio-geometric parameters have been calculated based on geomorphic surveys with auto-level (Sokkia C4 $4_{10}$ ), 100 metres tape and GPS (Garmin eTrex 30). Rosgen's model of 'Channel Classification' and related entrenchment ratio has been applied here for better understanding of stream conditions. Overall an empirical study has been carried out to show the impact of a road crossing on local level stream geomorphological forms and functions and its aquatic organisms. For temporal (2003, 2008, 2010, and 2011) change detection of this site Google Earth Imagery was retrieved and processed by Arc GIS 9.3 software.

\section{Result}

\section{At a-station variation}

To deal with spatial variations in channel properties at some reference reaches, at a-station hydraulic geometry study is the best way of progress (Knighton, 1984). Wolman (1955) stated that to work about local level channel geometry, cross-section form is a possible source of information. In this research work, to analysis the impact of road crossing on river morphology four cross-section sites were selected for detail study. Among these four sections, two were in upstream direction and two in downstream direction at 10 metres (D10) and 50 metres (D50) distance from the bridge. These four cross-sections were precisely helps us to quantify the variations between upstream and downstream channel morphology, as the indicators of impact of bridge on Kunur River. Firstly, with variation of channel mean (d) and maximum $\left(\mathrm{d}_{\max }\right)$ depth at each site, it has been observed that $d$ and $d_{\max }$ at downstream is greater than upstream, which indicates the role of bridge on bed degradation. High differences between $d$ and $d_{\max }$ in downstream $\quad\left(0.85-\mathrm{m} .{ }^{\mathrm{D} 10}, \quad 0.86-\mathrm{m} .{ }^{\mathrm{D} 50}\right)$ also indicates the presences of deep scours (Table 1). Cross-section area (A) in the both D10 crossing sites are greater than D50 (Table 1 and Fig. 2), which indicates back water affect for upstream reach and alternatively increased shear stress at the bank side due to diverts of flow towards bank by bridge piers for downstream reach. Here both of the upstream cross-sections indicates well developed floodplain with high entrenchment ratio $\left(2.27^{\mathrm{D} 10},>2.4^{\mathrm{D} 50}\right)$ and alternatively downstream sections indicates that river is moderately entrenched $\left(1.49^{\mathrm{D} 10}, 1.58^{\mathrm{D} 50}\right)$ and channel is vertically incised. High width-depth ratio in upstream sections $\left(39.15^{\mathrm{U} 10}, 36.59^{\mathrm{U} 50}\right)$ also proves the presence of extended floodplain than downstream section $\left(35.67^{\mathrm{D} 10}, 11.26^{\mathrm{D} 50}\right)$. After classified both upstream and downstream reach separately based on the 'Natural Stream Classification' model (Rosgen 1994; see Table 2), it is observed that upstream reach falls under ' $\mathrm{C} 5$ ' type and downstream section falls under 'B4' type (Table 1). 
Table 1 At a-Station Variation of Channel Parameters

\begin{tabular}{|c|c|c|c|c|}
\hline \multirow{2}{*}{ Channel Geometric Parameters } & \multicolumn{2}{|c|}{ Upstream of Bridge } & \multicolumn{2}{|c|}{ Downstream of Bridge } \\
\hline & 10m.(U10) & 50m.(U50) & 10m.(D10) & 50m.(D50) \\
\hline Mean Channel Depth at Bankfull Stage (d) & $1.35 \mathrm{~m}$ & $1.30 \mathrm{~m}$ & $1.55 \mathrm{~m}$ & $1.36 \mathrm{~m}$ \\
\hline Maximum Channel Depth at Bankfull Stage $\left(\mathrm{d}_{\max }\right)$ & $1.96 \mathrm{~m}$ & $1.92 \mathrm{~m}$. & $2.4 \mathrm{~m}$. & $2.22 \mathrm{~m}$. \\
\hline Deviation of $d_{\max }$ from $d$ & $0.61 \mathrm{~m}$ & $0.62 \mathrm{~m}$ & $0.85 \mathrm{~m}$ & $0.86 \mathrm{~m}$. \\
\hline Cross-Section Area (A) $\left(d^{*} w\right)$ in sq. $m$. & 72.40 & 63.14 & 89.59 & 20.84 \\
\hline Flow Velocity (v) in m./sec. & 0.21 & 0.25 & 0.22 & 0.42 \\
\hline Channel Width at Bankfull Stage (w) & $53.63 \mathrm{~m}$ & $48.67 \mathrm{~m}$ & $57.80 \mathrm{~m}$ & $15.32 \mathrm{~m}$. \\
\hline Flood prone Channel Width (wf) $\left(2 * \mathrm{~d}_{\max }\right)$ & $121.99 \mathrm{~m}$. & Undefined & $86.47 \mathrm{~m}$ & $24.27 \mathrm{~m}$. \\
\hline Entrenchment Ratio (ER) (wf/w) & 2.27 & $>2.4$ & 1.49 & 1.58 \\
\hline Sinuosity Index (S.I.) & 1.32 & & 1.16 & \\
\hline Width-Depth Ratio(W/D ratio) & 39.15 & 36.59 & 35.67 & 11.26 \\
\hline D50 (Median of Stream Material Size) in mm & Sandy & Sandy & Gravel & Gravel \\
\hline Stream Type (after Rosgen, 1994) & 'C5' & 'C5' & 'B4' & 'B4a' \\
\hline
\end{tabular}

*U (10/50) and S (10/50) indicate Upstream and Downstream reach respectively with Distance (m.) from bridge.

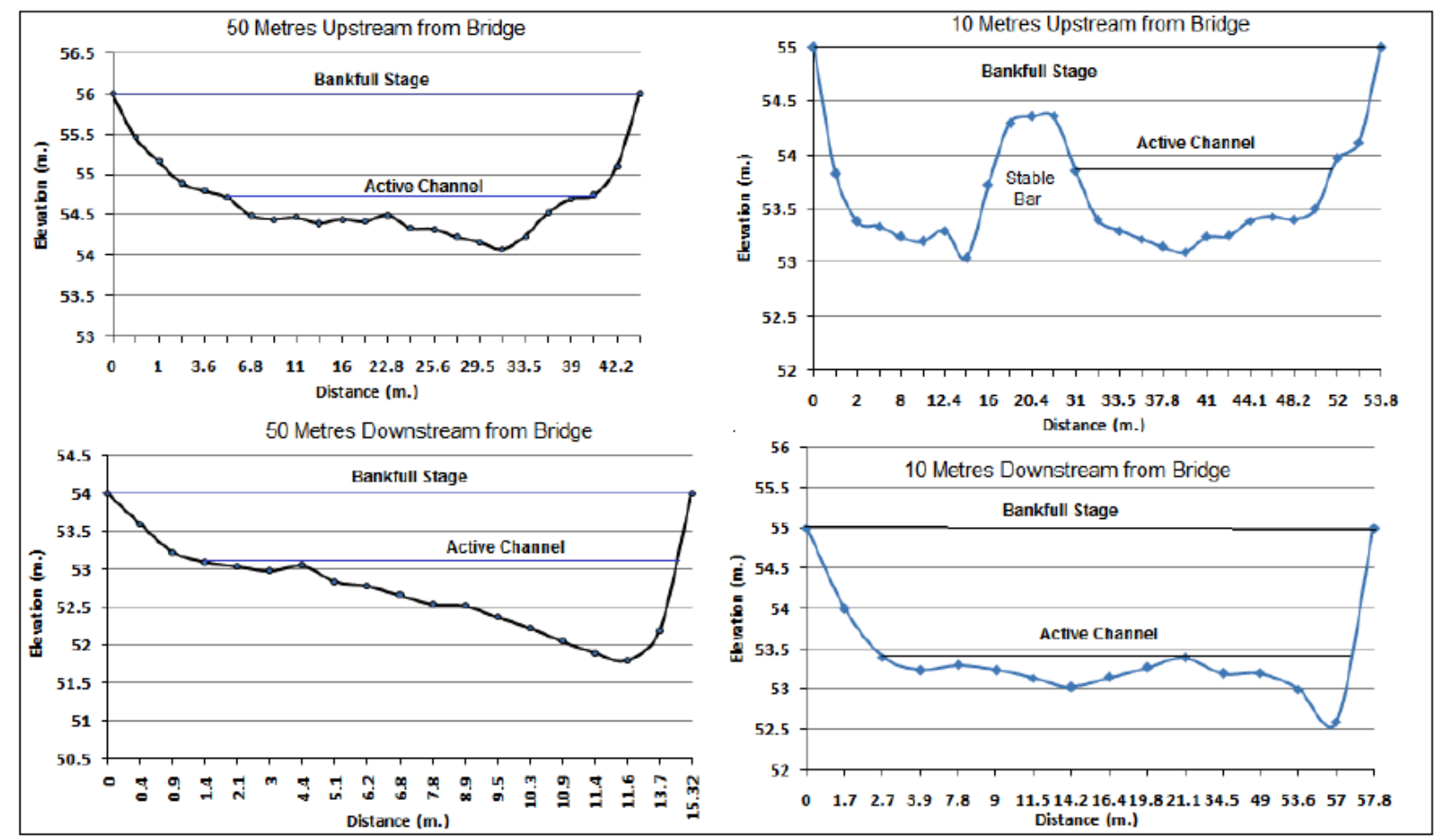

Figure 2 Bankfull Stage Cross-Sections of the Survey Reaches

\section{Pool-Riffle Sequence}

Richards (1976) very simply argued that pool and riffle as the negative and positive residuals from a trend line of channel bed topography respectively. Knighton (1984) defines pool and riffle from the sense of 'scale of distance' between the development of alternating deeps (pools) and shallows (riffles). He stated that these two significant features are spacing successively more or less at a distance of 5 to 7 times of channel width. Here, after surveyed an longitudinal profile along the thalweg line of 
Kunur River form one kilometre upstream to one kilometre downstream from that bridge, it has been observed that mean pool-pool and riffleriffle spacing of upstream $\left(259.82 \mathrm{~m}^{\text {pool-pool }}\right.$, $246.97 \mathrm{~m}$. riffle-riffle, with mean width of $51.15 \mathrm{~m}$.) is nearly doubled in the downstream reaches $\left(450.55 \mathrm{~m} .^{\text {pool-pool }}, 559.14 \mathrm{~m}\right.$. ${ }^{\text {riffle-riffle }}$ with $36.56 \mathrm{~m}$. of mean bankfull width) (Fig. 3). Average depth of pools in the upstream reaches is $0.51 \mathrm{~m}$., which is more than doubled in the immediate downstream $(2.45 \mathrm{~m}$.) from the bridge section. The variation of the ratio between average pool depth and riffle height in the upstream (0.59) and downstream (1.10) also indicates the presence of anomaly in pool-riffle sequences in the downstream reaches. Average channel bed gradient from pool to riffle and riffle to pool in the upstream reaches $\left(0.62^{\text {o pool-riffle }}, 0.61^{\text {riffle-pool }}\right)$ also increased in the downstream reaches $\left(0.84^{\circ}\right.$ pool-riffle, $0.77^{\mathrm{o}}$ riffle-pool $)$.

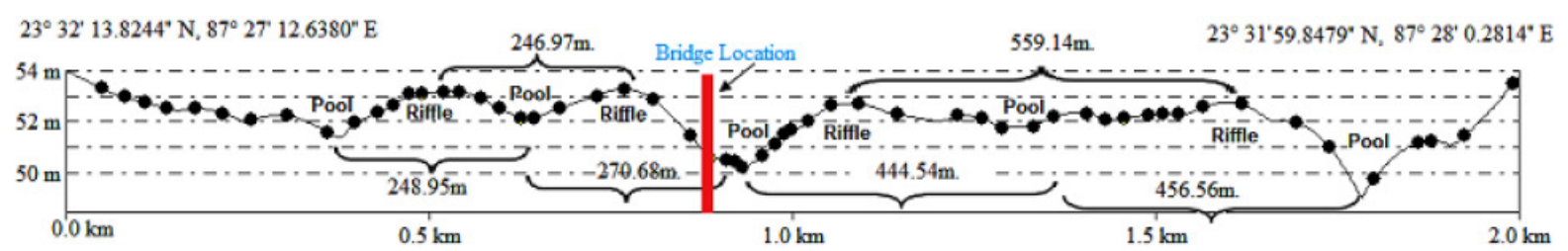

Figure 3 Longitudinal Profile of Survey Reach with Pool-Riffle Sequences

\section{Braided Index and Area of Bars}

Braided Index (BI) is a good device to detect the degree of stream bed load and rate of sediment deposition. It expressed by the double length of total bars or islands length that is divided by the total reach length (Brice, 1964). High value of BI indicates high rate of sedimentation and formation of longitudinal bars or islands. Braiding is more common in those regions which are characterised by human pressure (Bertoldi, 2004). In the study reach of Kunur River, BI gradually increased with time (Table 2) from 0.34 (2003) to 1.06 (2011). Particularly, rate of braiding is high in downstream $(73 \%)$ reach than upstream reach (63\%), which indicates the impact of bridge on the reach wise variation of sedimentation rate on channel bed (Table 2). Area occupied by bars within the channel also increased rapidly from $2003\left(805.69 \mathrm{~m}^{2}\right)$ to $2011\left(2818.97 \mathrm{~m}^{2}\right)$, where upstream reach occupies more area than downstream reach (Table $2 \&$ Figure 4). Number of bars are not increased with the same rate of BI $(\mathrm{r}=0.90)$ and total bar occupied area $(\mathrm{r}=0.88)$, which indicates the formation of stable islands with areal expansion.

Table 2 Temporal Changing Scenario of Braiding Index and Bar Occupied Area

\begin{tabular}{llllllll}
\hline \multirow{2}{*}{ Year } & \multicolumn{2}{l}{ Braided Index (BI) after Brice, 1964 } & \multicolumn{3}{l}{ Bar Occupied Area within Reach (m2) } & \\
& Total Reach & Upstream & Downstream & No. of Bar & Total Reach & Upstream & Downstream \\
\hline 2003 & 0.34 & 0.34 & 0.34 & 5 & 805.69 & 692.36 & 113.33 \\
2008 & 0.62 & 0.63 & 0.61 & 9 & 1540.43 & 1203.6 & 336.83 \\
2010 & 0.79 & 0.73 & 0.91 & 9 & 1853.37 & 968.3 & 885.07 \\
2011 & 1.06 & 0.94 & 1.27 & 10 & 2818.97 & 1545.48 & 1273.48 \\
\hline
\end{tabular}



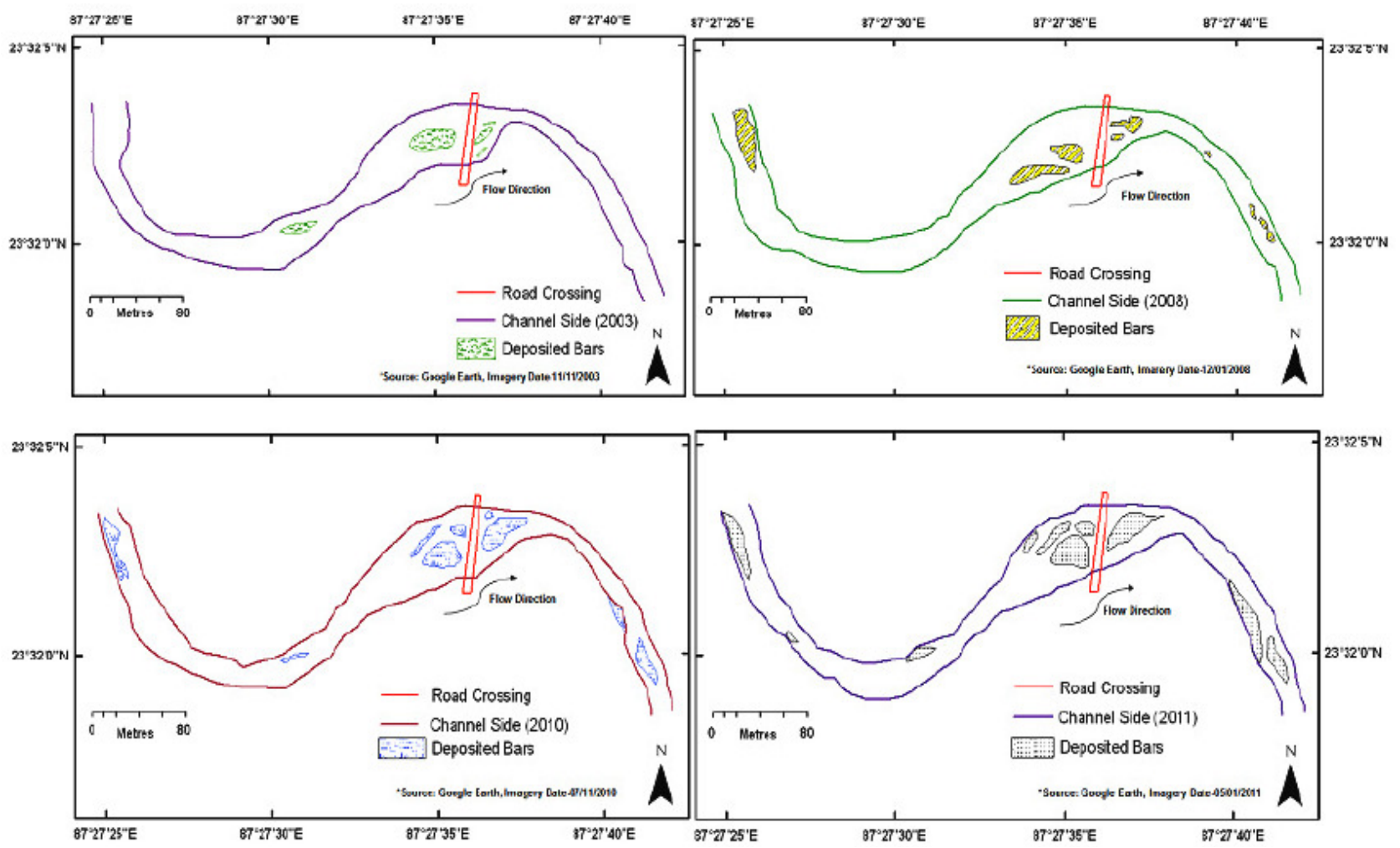

Figure 4 Temporal Bar Formation with Variation of Shape and Area in the Survey Reach

Aggradation-Degradation Characteristic (20032011)

Quantitative information from Table 3, related to channel depositional and erosional characteristics have been derived after superimpose the vector lines of study reach's bankfull channel outline of 2003 and 2011 years respectively (Fig. 5). After calculated the values related to temporal deposition and erosion for upstream and downstream, it has been observed that in the upstream reach depositional process is more dominated than erosion $\left(+913.71 \mathrm{~m}^{2}\right)$ but in the downstream reach erosional process is more dominated $\left(-1240.27 \mathrm{~m}^{2}\right)$ than deposition. To get proportional variation between these two reaches; ratios of aggradation (AR) and degradation (DR) have been calculated after dividing the reach wise area of deposition and erosion with reach wise total channel area (Table 3). Total channel area calculated after multiply the mean channel length and mean channel width of total laterally extended part from 2003 to 2011 years (Fig. 6). Aggradation and Degradation ratios also proved that in the upstream reach $\left(0.28^{\mathrm{AR}}, 0.22^{\mathrm{DR}}\right)$ deposition rate is more than erosion and in the downstream $\left(0.0 .13^{\mathrm{AR}}, 0.31^{\mathrm{DR}}\right)$ reach erosion rate is very high than deposition (Table 3). Rate of Instability also indicates that downstream reach $(0.18)$ is in more changeable than upstream reach (0.06). Sinuosity Index of both reaches also has variation due to changing channel planform. 
Table 3 Depositional and Erosional Characteristic of Study Area between "2003-2011"

\begin{tabular}{lcc}
\hline \multicolumn{1}{c}{ Parameters } & Upstream & Downstream \\
\hline Total Area of Deposition $\left(\mathrm{m}^{2}\right)$ & 4243.10 & 885.96 \\
Total Area of Erosion $\left(\mathrm{m}^{2}\right)$ & 3329.31 & 2126.23 \\
Difference of Deposition and Erosion $\left(\mathrm{m}^{2}\right)$ & +913.71 & -1240.27 \\
Mean Bankfull Width of Channel (m.) & 36.27 & 28.93 \\
Mean Length of Channel (m.) & 413.18 & 237.34 \\
Total Area of Reach (m ${ }^{2}$ ) & 14986.04 & 6866.25 \\
AR or Aggradation Ratio (Area of Deposition/ Total Channel Area of Study Reach) & 0.28 & 0.13 \\
DR or Degradation Ratio (Area of Erosion/ Total Channel Area of Study Reach) & 0.22 & 0.31 \\
Ratio of Instability (Difference between Erosion and Deposition/Total Channel Area & 0.06 & 0.18 \\
of Study Reach) & 1.32 & 1.16 \\
Sinuosity Index (Mean Valley Length/Channel Air Length) & & \\
\hline
\end{tabular}

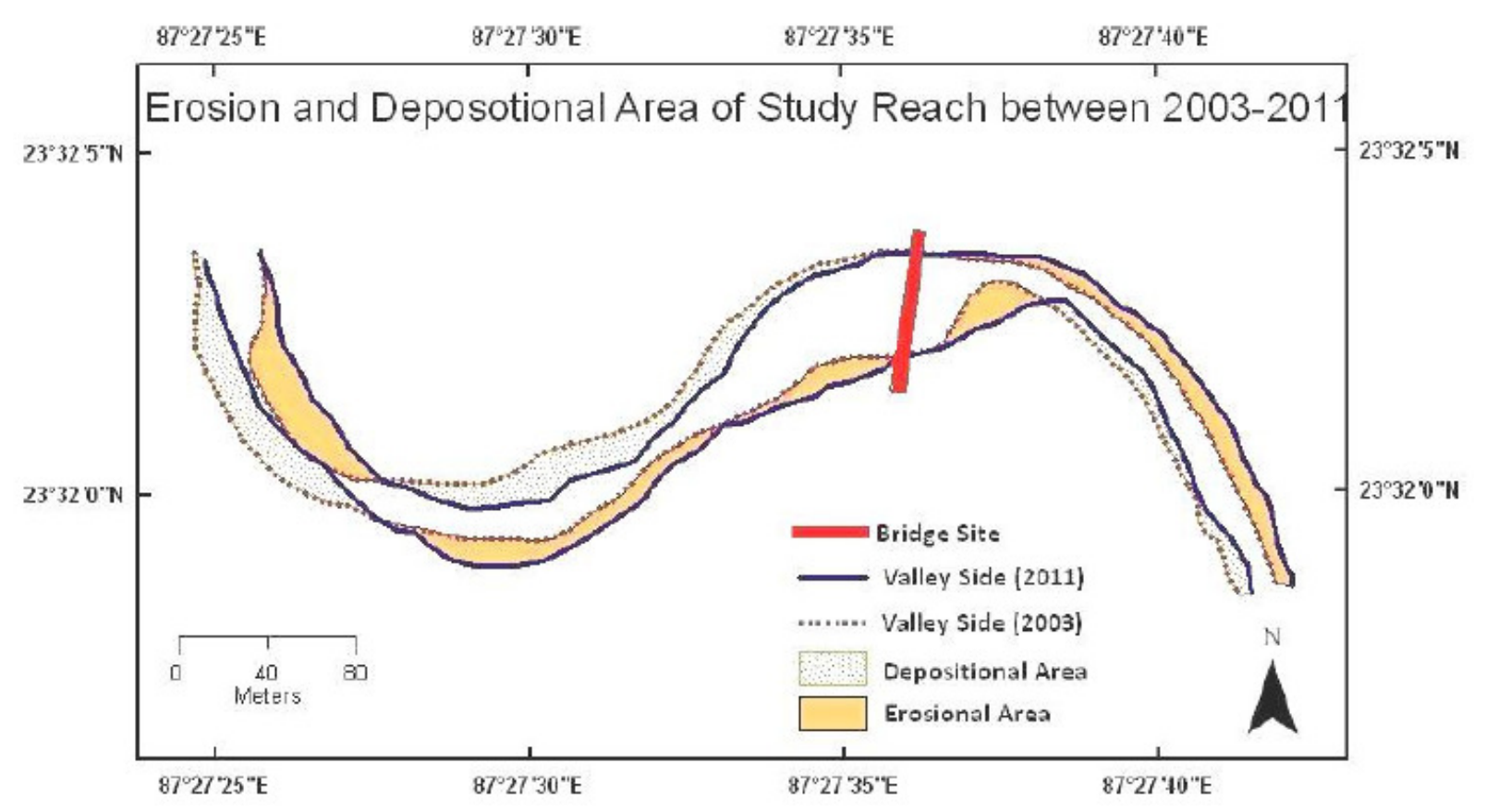

Figure 5 Aggradation and Degradation Characteristics 


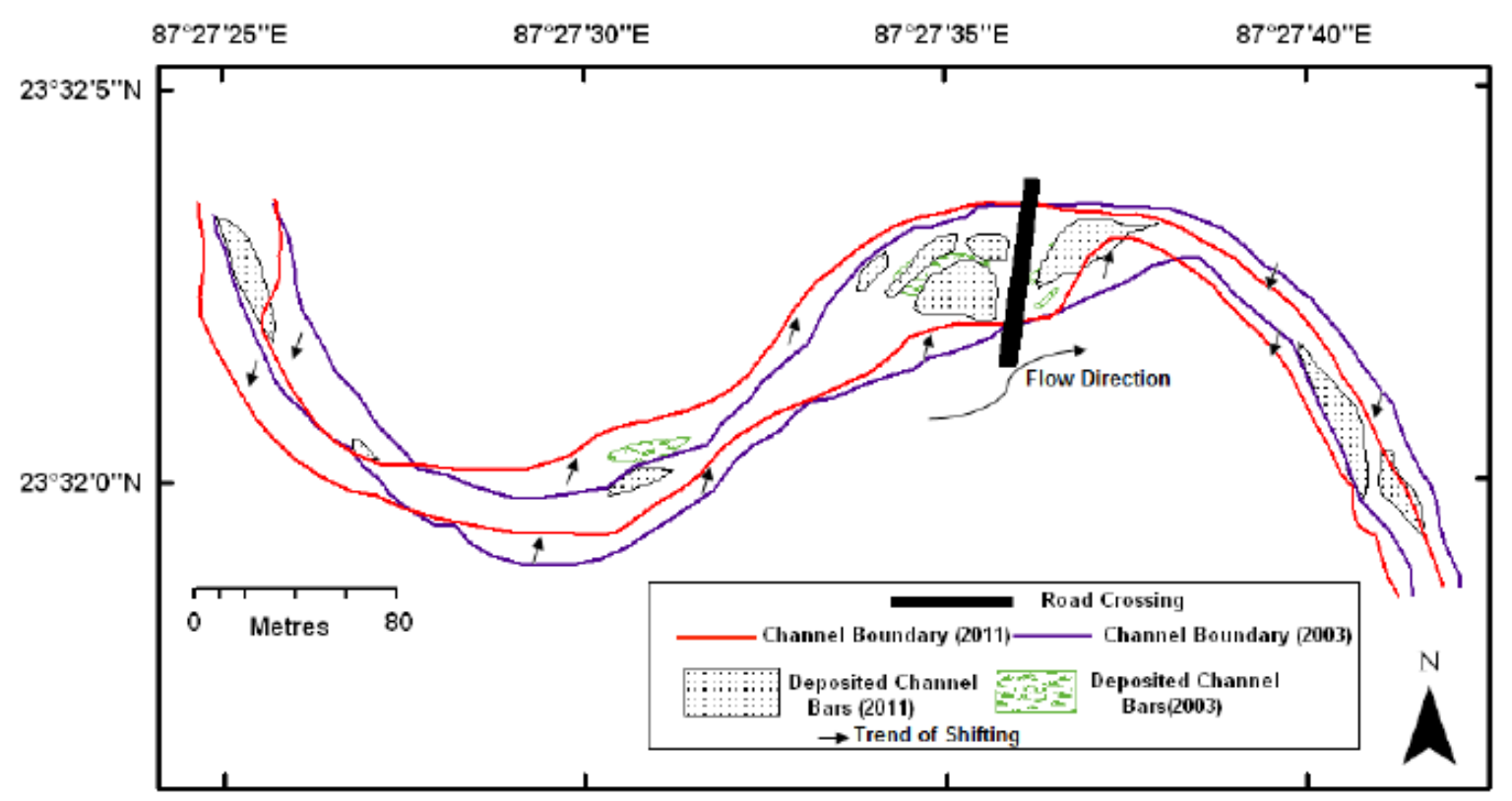

Figure 6 Temporal Shifting and Depositional Trend of Upstream and Downstream Reaches

\section{Discussion}

At a-station wise variations, pool-riffle sequences, BI, sinuosity index, aggradation ratio, degradation ratio, channel instability ratio all are supporting the existing fact of the impact of road crossing on river morphology and related fluvial processes. The increased cross-section area with low flow velocity, reducing the channel's sediment transport capacity and allowing sediment to deposited (Merril and Gregory, 2007). Increased sedimentation rates can bury aquatic life and leads to mid channel bar formation, which can deflect flows towards the banks causing further bank erosion (Frizzell et al., 2004). For the interconnected 10 bridge piers with thick concrete block on the river bed, during lean season Kunur's water cannot crosses the bridge over this concrete block. Therefore, water makes under way pass by drilling deep scours $(>2 \mathrm{~m}$.) below the concrete block to cross the bridge. As a result the bridge piers makes weak and unstable to standing over the river bed and have a great chance to collapse total bridge. Average pool depth and bed gradient in downstream are more than upstream, which indicates the high rate of erosion of downstream channel and bed incision. Table 2 and 4 helps to explore an interesting anomaly between BI and bar occupied area and related fluvial mechanism in the study reach. Correlation value (r) between bar occupied area and BI for total reach is 0.99 , but when correlates them only for upstream reach it is just 0.90 and for downstream 0.99 (Table 4). High bar occupied area and but low ' $r$ ' value in the upstream indicates huge sedimentation due to backwater affect and development of circular bars (Figure 6). Low bar occupied area than upstream but high ' $r$ ' value in the downstream elucidates the formation of longitudinal bars along with rapid water flow than upstream reach (Figures $4 \& 6$ ). Therefore, $\mathrm{BI}$ is high in the downstream reach than upstream but bar occupied area is in upstream reach.

Table 4 Correlation Values of Bar Occupied Area and BI in the Study Reach

\begin{tabular}{ccc}
\hline $\mathbf{X}$ & $\mathbf{Y}$ & 'r'-value \\
\hline Bar Occupied Area for Total Study Reach & BI for Total Study Reach & 0.99 \\
Bar Occupied Area for Upstream Reach & BI for Upstream Reach & 0.90 \\
Bar Occupied Area for Downstream Reach & BI for Downstream Reach & 0.99 \\
\hline
\end{tabular}


Rosgen's (1997) had presented river restoration methods using Natural Channel Design (NCD) that had been developed, tested, implemented and monitored for nearly four decades. He implemented eight phases of river restoration using Geomorphic Approach to NCD with several importance objectives on river planning. Based on Rosgen's restoration report, if the type of downstream stream reaches (B4) of the study area transformed into ' $\mathrm{C} 5$ ' type with increased width and ER of channel after removing stable islands from channel bed and fill incised part of the downstream by gravels and boulders. These steps will be helped to reduced bank erosion, channel incising, scour development, and bridge instability. As a result, a good floodplain will be developed in the downstream reach and making suitable habitat for floodplain ecosystem with aquatic organisms. Changing pool-riffle sequence in the study reach may alter the natural system of aquatic lives and creates threat for their lives. Unscientific design of this bridge makes a blockage for fish passage. VDFW (2009) pointed in their report, several impacts associated with crossing structure and with channel modification, which are necessary to install and repair for passage of fishes or aquatic organisms. They developed a common goal "to improve accommodation of wildlife and aquatic organism movement around and through transportation systems and to minimize habitat fragmentation resulting from the presence of transportation infrastructure" (VDFW 2009). For reducing the impact of man on river system, in terms of roadcrossing Bhattacharya (1958) had designed a pier less bridge for the Rupnarayan River with 600 feet width, which is a good engineering design for the construction of road crossing. This design should be followed by modern engineer to make eco-friendly road crossing.

\section{Conclusion}

Several problems have been encountered at this reach of Kunur River due to road crossing, which are cumulatively could be result of general grade change by long term changes of stream morphology. Major problem created with aggradation in the upstream channel and makes stable island and reducing mean channel depth. As a result, frequent flooding with increasing magnitude is a common phenomenon after any storm rainfall. On the other hand, degrading downstream reach affect bridge formation by reducing its pier's structural stability. In the United States, the annual damage related to hydraulic problem at bridges and highways has estimated at 100 million dollar during years of extreme floods (HIRE, 1990). These damages of stream can be reduced by considering channel stability in site selection, bridge design. Generally, alluvial channel are unstable in nature, therefore during engineering actions over these channels, knowledge about changing or shifting tendency of these rivers, local geology, channel degradation and aggradation rate, channel geometric characteristics should be under consideration. This study has demonstrated the needs of understanding the fluvial dynamics of any channel reach, whenever undertaking of river crossing programme. Form engineering point of view, it is impossible to produce a completely stable ecologically balanced and stable geomorphic condition of any stream reach after construction any diversion (Gilvear and Bradley, 1997). Bhattacharya (1958), a famous consulting civil engineer in Bengal, said that "for the construction of any bridge up to 800feet (244-m.) across the river, it can easily construct without any piers and make low constructional cost". Therefore, in the study area 10 piers for only 87 metres long bridge is a strong evident of how single unscientific human activities can also alter the river morphology and its aquatic life. Therefore, during any engineering plans within river system needs to consult with expert fluviogeomorphologists, hydrologists, ecologists and brilliant engineers for preparation of genius long term report on Environmental Impact Assessment (EIA) of that construction over river.

\section{References}

Abbe, T.B. and Montgomery, D.R. (2003), Patterns and processes of wood debris 
accumulation in the Queets river basin, Washington. Geomorphology, 51, 81-107.

Bertoldi, W. (2004), River Bifurcations. Thesis $(P h D)$, University of Trento, Italy.

Bhattacharya, K. (1959), Bangladesher Nad-Nadi o Parikalpana (in Bengali). Calcutta: Bidyadoya Library Ltd.

Blanton, P. and Marcus, W.A. (2009), Railroads, roads and lateral disconnection in the river landscapes of the continental United State. Geomorphology, 122, 212-227.

Bouska, W.W., Timothy Keane and Paukert, C.P. (2010), The Effects of Road Crossings on Prairie Stream Habitat and Function. Journal of Freshwater Ecology, 25(4), 499-506.

Brice, J.C. (1964), Channel pattern and terraces of the Loup River in Indiana. US Geol. Survey Prof. Paper, 422-D.

Frizzell, R.L., Zevenbergen, L.W. and Navarro, R. (2004), Stream Channel restoration at Bridge Sites. Trimble Inc. 6445 Powers Ferry road, Suite 100, Atlanta, GA 30339, 1-9.

Geological Survey of India (2001), District Resource Map, Barddhaman, West Bengal, Govt. of India.

Gilvear, D. and Bradley, S. (1997), Geomorphological Adjustment of a Newly Engineered Upland Sinuous Gravel-Bed River Diversion: Evan Water, Scotland. Regulated Rivers: Research \& Management, 13, 377-389.

Grade, R.J. and Kothyari, U.C. (1998), Scour around Bridge Piers. PINSA 64(A) 4, 569-580.

Gregory, K.J. and Brookes, A. (1983), Hydrogeomorphology Downstream from Bridges. Applied Geography, 3, 145-159.

Highways in the River Environment (HIER) (1990), Manual for river environment conservation, Federal Highway Administration, FHWA-HI-90-016,

Hancock, P.J. (2002), Human Impact on the Stream-Groundwater Exchange Zone. Environmental Management, 29(6), 763-781, doi: 10.1007/s00267-001-0064-5.

Jackson S. D. (2003), Design and construction of aquatic organism passage at road-stream crossings: ecological considerations in the design of river and stream crossings. In: C. L. Irwin, P.
Garrett, and K. P. McDermott, (Ed.) Proceedings of the International Conference on Ecology and Transportation. Center for Transportation and the Environment, North Carolina State University, Raleigh, NC, 20-29. Available from: http://ag.umass.edu/sites/ag.umass.edu/files/intere st-topic-

pdfs/ecological_considerations_stream_crossings. pdf

Jones, J.A., Swanson, F.J., Wemple, B.C. and Synder, K.U. (2000), Road effect on hydrology, geomorphology, and disturbance patches in stream network. Conservation Biology, 14, 76-85. Knighton, A. D. (1984), Fluvial Forms and Processes. Edward Arnold, Sheffield, North America.

Kothyari, U.C. and Ranga-Raju K. G. (2000), Scour around spur dikes and bridge abutments. JOURNAL OF HYDRAULIC RESEARCH, 39(4), 367-374.

McKenney, R., Jacobson, R.B. and Wetheimer, R.C. (1995), Woody Vegetation and Channel Morphogenesis in Low Gradient Gravel-Bed Streams in the Ozark Plateaus, Missouri and Arkansas. Geomorphology, 13, 175-198.

Merril, M.A., Gregory, J. (2007), The Effects of Culverts and Bridges on Stream Geomorphology. In: Jay F. Levine et al., (Ed.) Technical Report (FHWA/NC/2006-15) on A comparison of the Impacts of Culverts versus Bridges on Stream Habitat and Aquatic Fauna, NC State University and NC Museum of Natural Sciences, Raleigh, 15-45.

Niyogi, M. (1985), Ground Water Resource of the Ajay Basin, In: Prof. S.P. Chatterjee, (Ed.) Geographical Mosaic- Professor K.G. Bagechi felicitation Vol., Manasi Press, Calcutta, 165-182. Orth, D.J. and R.J. White. (1999), Stream habitat management. In: Kohler, C.C. and W.A. Hubert, ed. Inland fisheries management in North America, 2nd edition. American Fisheries Society, Bethesda, Maryland, 249-284.

Paul Blanton, P. and Marcus, W.A. (2009), Railroads, roads and lateral disconnection in the river landscapes of the continental United States. Geomorphology, 112, 212-227, doi: 10.1016/j.geomorph.20 09.06.008 
Resh, V.H. (2005), Stream crossings and the conservation of diadromous invertebrates in South Pacific island streams. Aquatic Conservation: Marine and Freshwater Ecosystems, 15, 313-317. Richardson, E.V. and Richardson, J.R. (1999), Determining Contraction Scour. In: E.V. Richardson and P.F. Lagasse, (Ed.) Stream Stability and Scour at Highway Bridges, American Society of Engineers, 483-490.

Richards, K.S. (1976), The morphology of rifflepool sequences. Earth Surface Processes, 1, 7188.

Robert, A. (2003), River Processes. Arnold, London.

Rosgen, D.L. (1994), A classification of natural rivers. Catena, 22,169-199.

Rosgen, D.L. (1997), A Geomorphological Approach to Restoration of Incised Rivers. In: S.S.Y. Wang, E.J. Langendoen and F.D. Shields, (Ed.) Management of Landscapes Disturbed by Channel Incision. Available from: http://www.wildlandhydrology.com/assets/A_Geo morphological_Approach_to_Restoration_of_Inci sed_Rivers.pdf

Simon, A. and Johnson, P.A. (1999), Relative Roles of Long Term Channel Adjustments Processes and Scour on the Reliability of Bridge Foundations. In: E.V. Richardson and P.F. Lagasse, (Ed.) Stream Stability and Scour at Highway Bridges. American Society of Civil Engineers, 151-165.

Sing, S. (1983), Flood Hazard and environmental degradation: a case study of the Gomti River. In: L.R. Sing, (Ed.) Environmental Management, Allahabad Geographical Society, Department of Geography, Allahabad University, 271-286.

Vannote, R.L., Minshall, G. W., Cummins, K.W., Sedell, J.R., and Cushing, C.E. (1980), River Continuum Concept. Canadian Journal of Fisheries and Aquatic Sciences, 37(1), 130-137. Vermont Department of Fish and Wildlife (2005), Vermont's Wildlife Action Plan. Available from: http://www.vtfishandwildlife.com/swg_cwcs_rep ort.cfm

Vermont Department of Fish and Wildlife (2009), Guidelines for the Design of Stream/Road Crossings for Passage of Aquatic Organisms in Vermon. Available from: http://www.google.com/url?sa=D\&q=http://www. vtfishandwildlife.com/library/Reports_and_Docu ments/Aquatic+Organism+Passage+at+Stream $+\mathrm{C}$ rossings/_Guidelines+for+the+Design+of+Stream _Road+Crossings+for+Passage+of+Aquatic+Org anisms+in+Vermont.pdf\&usg=AFQjCNHFYBIg Siwrs8UkfbTtS56eWefmDg

Wang, J., Edwards, P.J. and Goff, W.A. (2010), Assessing Changes to In-Stream Turbidity Following Construction of a Forest Road in West Virginia. TMDL 2010 Watershed Management to Improve Water Quality CD-ROM Proceedings, ASABE Publication Number 711P0710cd.

Waters, T. F. (1995), Sediment in streams: sources, biological effects, and control. American Fisheries Society, Bethesda, MD, Monograph 7.

Wellman, J.C., Combs, D.L. and Cook, B. (2000), Long-Term Impacts of Bridge and Culvert Construction or Replacement on Fish Communities and Sediment Characteristics of Streams. Journal of Freshwater Ecology, 15(3), 317-328.

Wemple, B.C., Swanson, F.J. and Jones, J.A. (2001), Forest roads and geomorphic process interactions, Cascade range, Oregon. Earth Surface Processes and Landforms, 26, 191-204.

Wheeler, P.A., Angermeier, P. L. and Rosenberger, A.E. (2005), Impact of New Highways and Subsequent Landscape Urbanization on Stream Habitat and Biota. Reviews in Fisheries Science, 13(3), 141-164. Wolman, M.G. (1955), The natural channel of Brandywine Creek, Pennsylvania. United States Geological Survey Professional Paper, 271, 56. 